\title{
Case Study: Fund Raising in a Financial Crisis: Concordia University, River Forest, Illinois
}

\begin{abstract}
Alan Klaas
Dr. Alan Klaas is Senior Vice President for university advancement at Concordia University-River Forest. Prior experience includes five years consulting to organizations facing serious business problems, 15 years as an officer of a Fortune 500 corporation in marketing, research, and development, where he launched a successful banking operation, and five years on the graduate faculty of a large university.
\end{abstract}

Concordia University in River Forest, Illinois, was established during the Civil War and for 120 years was a college exclusively training teachers and church workers for the Lutheran ChurchMissouri Synod. Today the University is a private liberal arts university offering 37 undergraduate and 17 graduate degrees.

Over five years, an underfunded $\$ 50 \mathrm{~m}$ building program, chronic operating losses, and a 30 percent enrollment decline, created the "perfect storm" of financial crisis. Facing financial exigency (polite nonprofit talk for bankruptcy), radical change was required. Beloved faculty and staff were "released with regret," biweekly payrolls were often in doubt, and rumors grew daily.

How do you raise money in such dire circumstances? With clarity, integrity, and careful thought. Given the pressure, the "careful thought" was the greatest challenge.

We adopted three fundamental principles. First, we did not launch the "give or we will close" alert and appeal. This "doomsday device" has three challenges. People prefer to give to health, new freshmen avoid schools about to close, and the doomsday device is a card you can only play once. It may have been needed if bankruptcy occured.

Secondly, we did not approach donors until we had clearly understood and exclusively addressed the underlying problems. Rising short-term debt and inability to support new long-term debt were symptoms of a more fundamental issue. The core problem was enrollment declines caused by a stagnant curriculum held hostage by a tradition-bound "the way we used to do things" approach. The governing regents responded by requiring the faculty to update the curriculum in record speed and key leadership transitions took place.

Thirdly, the message delivered to the donors was fair to all and described actions taken rather than the many ideas and options being considered. It proved critical that our plan made realistic sense. Donors can detect the difference between wishful thinking and reality.

The result? In the last two years enrollment is up 30 percent, net income is up 40 percent, even debt is reduced 16 percent with refinancing saving one half million dollars per year. Best of all, major donors continue to give, with many increasing their support. 